\title{
PERSEPSI GURU PENDIDIKAN KEWARGANEGARAAN TERHADAP MENGUATNYA POLITIK IDENTITAS DI KECAMATAN KETUNGAU HILIR
}

\author{
Juri \\ STKIP Persada Khatulistiwa Sintang, Pendidikan Pancasila dan Kewarganegaraan, Sintang \\ Email: jurisaputra85@gmail.com.
}

\begin{abstract}
Abtract
This research is based on the assumption that there are still many PKn teachers who tend to be apathetic with politics.According to them, politics is only a dynamic cycle of government in the mobilization of officials who will lead the country five years. Such apathy, is actually not without reason.That is, teachers feel there is no meaningful change when they are involved in politics.The next, those who are civil servants are not allowed to participate in politics.The method used in this research is descriptive qualitative, where researchers only describe systematically the perception of Civics teachers, both at the junior and senior high school level on the political culture in the Ketungau Hilir sub-district.The results of this study indicate that the perception of Civics teachers on political culture in the Subdistrict of Ketungau Hilir tends to strengthen identity politics based on SARA elements.
\end{abstract}

Keywords: Identity politich, PKn Teachers, Ketungau Hilir Sub-Districh 


\begin{abstract}
Abstrak
Penelitian ini bertolak dari anggapan bahwa guru-guru PKn masih banyak yang cenderung apatis dengan politik. Menurut mereka, politik hanyalah sebuah dinamika siklus pemerintahan dalam mobilisasi pejabat yang akan memimpin negeri ini lima tahunan. Keapatisan tersebut, sebenarnya bukan tanpa alasan. Artinya, para guru merasa tidak ada perubahan yang berarti ketika mereka terlibat dalam politik. Yang berikutnya, bagi mereka yang berstatus sebagai pegawai negeri secara atruan tidak diperbolehkan ikut berpolitik. Metode yang digunakan dalam penelitian ini adalah kualitatif deskriptif, dimana peneliti hanya menggambarkan secara sistematis mengenai persepsi guru PKn, baik pada tingkat SMP dan SMA terhadap budaya politik di kecamatan Ketungau Hilir. Hasil penelitian ini menunjukkan bahwa persepsi guru-guru PKn terhadap budaya politik di Kecamatan Ketungau Hilir cenderung menguatnya politik identitas berdasarkan unsur SARA.
\end{abstract}

Kata Kunci: Politik Identitas, Guru PKn, Kecamatan Ketungau Hilir 


\section{A. Pendahuluan}

Politik merupakan kebutuhan bagi setiap negara dengan sistem pemerintahan demokrasi.Ini dikarenakan politik merupakan usaha atau strategi untuk mencapai dan mempertahankan kekuasaan.Diamond (2003:97) menyatakan,politik adalah suatu usaha untuk mencapai masyarakat politik (polity) yang terbaik di dalam politik, manusia akan hidup bahagia karena memiliki peluang untuk mengembangkan bakat hidup dengan rasa kemasyarakatan yang akrab dan hidup dalam suasana moralitas.

Indonesia merupakan salah satu negara dimana politik merupakan cara ataupun langkah-langkah untuk mencapai kekuasaan. Cara tersebut dilaksanakan sebagai wujud implementasi demokrasi, yakni pemerintahan dari, oleh dan untuk masyarakat. Salah satu contoh wujud implementasi demokrasi tersebut adalah melalui pemilu. Ketika pemilu, rakyat diberi kebebasan untuk menyalurkan hak pilihnya sesuai hati nurani. Artinya, dalam memilih, tidak diperkenankan ada pemaksaan dari pihak manapun juga, baik dengan cara halus maupun kasar. Keikutsertaan seseorang maupun kelompok dalam pemilu merupakan faktor penting guna mensukseskan pembangunan berkelanjutan.Hal ini sesuai dengan isi Undang-Undang Republik Indonesia Nomor 39 Tahun 1999, pasal 4 Ayat (1), “Setiap warganegara berhak untuk dipilih dan memilih dalam pemilihan umum berdasarkan persamaan hak melalui pemungutan suara yang langsung, umum, bebas, rahasia, jujur dan adil sesuai dengan ketentuan peraturan perundang-undangan”.

Namun, semua kegiatan seharusnya disertai rasa sukarela sebagai tindak spontanitas individu maupun kelompok masyarakat dalam partisipasi politik. Dengan kegiatankegiatan politik ini pula, intensitas tingkat partisipasi politik masyarakat dapat terdeteksi, terutama mengenai budaya politik di suatu daerah. Oleh sebab itu, sikap dan perilaku masyarakat dalam kegiatan politik berupa pemberian suara dan kegiatan kampanye dalam pemelihan umum merupakan parameter untuk mengetahui tingkat partisipasi politik warga.

Menguatnya politik identitas saat ini cenderung bisa memperburuk suasana perpolitikan di negeri ini. Hal tersebut kemungkinan bisa terjadi apabila semua pihak pada akhirnya 
tidak mampu memisahkan antara kepentingan bersama dengan kepentingan golongan. Sebab, kedua kepentingan tersebut sama-sama mempunyai porsi yang sama. Hanya saja, sebagai kaum akademisi, kedua kepentingan tersebut jangan sampai dibenturkan. Penguatan politik identitas menurut pandangan sebagian besar guru PKn khususnya di Kecamatan Ketungau Hilir sangat penting, sebab untuk menunjukkan identitas diri. Namun, bagi sebagian kecil, politik identitas tersebut perlahan bisa membahayakan tatanan kehidupan berbangsa dan bernegara, sebab masing-masing etnik ingin menonjolkan diri dan cenderung menganggap etnik lain berada di bawah.

Di Kecamatan Ketungau Hilir, saat pemilu banyak yang menerima uang dari kandidat untuk mendukung calon yang telah memberikan uang tersebut. Masyarakat berpandangan pemilu-pemilu yang akan datang tidak ada bedanya dengan pemilu-pemilu sebelumnya, karena perilaku masyarakat dan kandidat soal pemberian uang seakan sudah membudaya.Pemimpin cenderung lebih banyak datang pada masyarakat ketika kampanye.Namun, pada akhirnya lupa akan semua janji serta visi dan misinya.
Parahnya lagi bukan hanya sekedar masyarakat biasa atau swasta yang seperti ini tetapi guru atau Pegawai Negeri Sipil (PNS) juga demikian. Tingkah laku politik demikian sebenarnya dipengaruhi oleh hilangnya kepercayaan masyarakat terhadap pemimpin dan kebutuhan pemimpin atau calon pemimpin kepada masyarakat yang hanya sesaat saja.

Masyarakat lebih cenderung mementingkan uang dibandingkan memilih sesuai hati nurani. Disisi lain,ada juga masyarakat yang telah menerima uang untuk memilih kandidat tertentu, namun ketika di bilik suara, mereka memilih kandidat lain, sesuai hati nuraninya.

\section{B. Metode}

Metode merupakan cara yang dilakukan seseorang guna mengerjakan sesuatu. Tidak semua metode cocok dipakai dalam setiap jenis dan jenjang pekerjaan. Karena itu, manusia dituntut untuk memilih metode yang tepat sesuai jenis pekerjaannya,dengan harapan pekerjaan tersebut dapat diselesaikan secara cepat, tepat dan mendapatkan hasil yang akurat.

Demikian juga dalam sebuah penelitian, memerlukan cara yang tepat sesuai permasalahan yang diangkat. 
Umumnya, pendekatan yang sering digunakan adalah kualitatif, kuantitaf, reading dan delevopment $(\mathrm{R} \& \mathrm{D})$ dan mixed (campuran antara kualitatif dan kuantitatif). Semua jenis pendekatan penelitian tersebut, pada dasarnya mempunyai kelebihan maupun kekuarangannya masing-masing.

Nawawi, (2007:65 \& 67$)$ mengatakan bahwa metode penelitian adalah cara yang dipergunakan untuk mencapai tujuan. Lebih lanjut dikatakan bahwa metode deskriptif adalah prosedur pemecahan masalah yang diselidiki dengan menggambarkan atau melukiskan keadaan subyek atau obyek penelitian (seseorang, lembaga, masyarakat dan sebagainya) pada saat sekarang berdasarkan fakta yang tampak atau sebagaimana mestinya.

Metode ataupun pendekatan yang digunakan dalam penelitian ini adalah kualitatif deskriptif. Sugiyono, (2011:15) mengatakan, metode penelitian kualitatif merupakan metode penelitian yang berlandaskan pada filsafat postpositivisme, digunakan untuk meneliti pada kondisi obyek yang alamiah, (sebagai lawannya adalah eksprimen) dimana peneliti adalalah sebagai instrument kunci (key intrument), pengambilan sampel sumber data dilakukan secara purposive dan snowball, teknik pengumpulan dengan triangulasi (gabungan), analisis data bersifat induktif atau kualitatif, dan hasil penelitian kualitatif lebih menekankan makna dari pada generalisasi.

Sementara itu, Kirk dan Miller sebagaimana dikutif Nasution (2003:23) berargument bahwa penelitian kualitaitf awal mulanya bersumber pada pengamatan kualitaitf yang dipertentangkan dengan pengamatan kuantitatif. Lalu mereka mendefinisikan,metodologi kualitatif adalah tradisi tertentu dalam ilmu pengetahuan sosial yang secara fundamental bergabung pada pengamatan terhadap manusia dalam kekhasasannya tersendiri dan berhubungan dengan orang-orang tersebut dalam bahasanya dan dalam peristilahannya.

Dilain pihak, Bogdan dan Biklen (1992:21-22) menyatakan bahwa penelitian kualitaitf adalah salah satu prosedurpenelitian yang menghasilkan data deskriptif berupa ucapan atau tulisan perilaku orang-orang yang diamati. Dipaparkan lebih lanjut bahwa penelitian kualitatif diharapkan mampu menghasilkan uraian mendalam tentang 
ucapan, tulisan dan atau perilaku yang dapat diamati dari suatu individu, kelompok, masyarakat dan atau suatu organisasi tertentu dalam suatu setting konteks yang dikaji dari sudut pandang yang utuh, komprehensif dan holistik.

$$
\text { Selanjutnya, Muhadjir }
$$

(1996:243) menyatakan pendapatnya mengenai penelitian kualitatif. Ia berasumsi, penelitian kualitaitf lebih mengutamakan pada masalah proses dan makna/persepsi dimana penelitian ini dapat mengungkap berbagai informasi kualitatif dengan deskripsianalisis yang teliti dan penuh makna, yang juga tidak menolak informasi kuantitatif dalam bentuk angka maupun jumlah. Pada tiap obyek akan dilihat kecenderungan, pola pikir, ketidakteraturan, serta tampilan perilaku dan integrasinya sebagaimana studi kasus genetik.

Metode kualitatif deskripttif ini sengaja dipilih karena peneliti hanya mendeskripsikan fakta yang diperoleh di lapangan secara alami, tanpa terkontaminsasi persepsi peneliti. Segala yang didengar, dilihat maupun dirasakan selama berada dilapangan, diolah dengan pisau analisis secara mendalam guna memperoleh data yang sesuai permasalahan dan dapat dipertanggungjawabkan secara ilmiah.

Sukmadinata

menyatakan,penelitian deskriptif adalah suatu bentuk penelitian yang paling dasar dan ditujukan untuk mendeskripsikan atau menggambarkan fenomena-fenomena yang ada, baik fenomena yang bersifat alamiah ataupun rekayasa manusia. Di sisi lain, Nawawi, (2007:68) berpendapat bahwa penelitian deskriptif mempunyai cirinya tersendiri, antara lain: (1) memusatkan masalah yang ada pada saat penelitian dilakukan atau masalah yang bersifat aktual, (2) menggambarkan fakta tentang masalah yang diselidiki sebagaimana adanya, diiringi dengan interpretasi rasional yang adequate.

\section{Pembahasan dan Hasil}

1. Pembahasan

a. Persepsi Guru PKn SMP Kecamatan Ketungau Hilir terhadap Politik Identitas

Guru merupakan sosok orang yang dianggap bisa dalam segala bidang. Disamping itu, guru juga diidentikkan sebagai orang yang mampu menjadi panutan, baik dalam perbuatan, perkataan maupun perilaku di masyarakat. Karena itu, ketika guru 
mengarahkan masyarakat terhadap kandidat tertentu, biasanya masyarakat banyak yang mengikuti.

Ketika peneliti mewawancarai guru-guru PKn di Kecamatan Ketungau Hilir, mereka mengatakan bahwa politik identitas pada dasarnya diperlukan untuk menunjukkan siapa diri kita. Kita mestinya tidak boleh mengabaikan masalah identitas. Sebab, identitas tersebut melambangkan darimana kita berasal. Disamping itu, identitas juga melambangkan serangkaian kebudayaan yang berlaku di suatu daerah. Dengan demikian, antara politik identitas dengan budaya politik, sebenarnya tidak dapat dipisahkan, sebab keduanya merupakan dua unsur yang saling mendukung dalam proses politik di tanah air.

Melalui identitas yang dimiliki seseorang, (katakanlah KTP), orang lain dapat mengerti bahwasannya individu bersangkutan, misalnya bernama Masalina, beragama Katolik, umur 30 tahun, asalnya dari Sebaruk 1, Desa Sungai Mali, dan seterusnya.

Dalam politik, identitas demikian menjadi penting, sebab secara terselubung para kandidat maupun pemilih, perlahan berorientasi merangkul orang yang mempunyai kesamaan agama dan suku. Walaupun disisi lain, ketika kampanye, memakai embel-embel SARA tidak diperkenankan, sebab bertentangan dengan peraturan perundang-undangan yang berlaku. Ini senada dengan ungkapan yang disampaikan salah seorang guru PKn di SMP 5, berinisial S. Ia menyatakan bahwa identitas kita jangan sampai dihilangkan atau bahkan kita justru malu mengaku siapa diri kita sebenarnya. Menurutnya, politik identitas ini sangat penting untuk mempertahankan jati diri sebagai anak bangsa.

Lebih lanjut ia menambahkan bahwa yang menjadi permasalahan adalah identitas seringkali disalahartikan dan cenderung mengabaikan keberagaman. Di Indonesia, jika keberagaman ditinggalkan, maka malapetaka pasti akan datang menghampiri. Sebab, melalui keberagaman bangsa ini didirikan oleh pendahulu kita. Mereka berasal dari latar belakang yang berbeda, namun tidak pernah mempermasalahkannya.

Responden lainnya, berinisial A, guru PKn di SMP 4. Ia mengatakan bahwa secara umum, politik identitas sangat diperlukan dalam membangun 
suatu bangsa. Sebab, tanpa politik identitas, suatu bangsa akan kehilangan arah. Selama ini, kita akui bersama bahwa menguatnya politik identitas mulai mengarah pada persaingan yang tidak sehat. Ini dikarenakan masingmasing individu mulai menjagokan kandidat berdasarkan kesamaan suku dan agama.

Disamping itu, kita dapat melihat bahwa spanduk yang terpasang di daerah tertentu hanya kandidat tertentu pula yang mempunyai kesamaan suku dan agama dengan masyarakat setempat. Kalaupun ada sepanduk yang terpasang di suatu daerah, namun kandidatnya bukan dari suku dan agama yang sama, maka peluang untuk menang kecil.

Responden berinisial $\mathrm{T}$, salah seorang guru di SMP 6 mengatakan bahwa menguatnya politik identitas sebenarnya sudah sejak lama. Hanya saja, di kalangan masyarakat kita di pedalaman baru disadari akhir-akhir ini. Selama pemerintahan Orde Baru dan setelah Orde Reformasi berjalan sekitar 20 tahun terakhir, kemungkinan besar masih banyak masyarakat di pedalaman yang belum menyadari bahwa para kandidat yang mencalonkan diri sebagai anggota legeslatif selalu menggunakan simbol agama dan suku, walaupun belum secara terang-terangan.

Menurutnya, fakta di atas kiranya perlu dijelaskan kepada seluruh masyarakat pada tataran Grass Roots, supaya mereka bangun dari tidur panjang dan segera menyadari bahwa sebenarnya kita telah hidup dalam politik identitas tersebut. Selama ini, ada indikasi bagi kalangan masyarakat tertentu yang selalu mempolitisir bahwa hanya kalangan tertentu saja yang bisa bertarung dan memenangkan pemilihan di negeri ini. Disadari atau tidak, fakta tersebut sudah lama menggema.

Disisi lain, masyarakat dari etnis minoritas perlahan mulai menunjukkan taringnya yakni bergabung dalam partai politik. Melalui partai politik, mereka bisa ikut menentukan kebijakan yang dibuat pemerintah. Dengan keikutsertaan tersebut, mereka berkeyakinan bahwa kebijakan tersebut mampu berpihak pada masyaraakt kecil yang telah mempercayakan sebagian haknya pada wakilnya.

Responden berinisial M, guru PKn di SMP 7 berasumsi bahwa dimana-mana di dunia ini, politik identitas selalu menjadi trends dalam menentukan arah pembangunan. 
Contohnya, ras kulit hitam dan putih di Amerika. Namun, rakyat bersama pemerintah mampu mengolah perbedaan sehingga negaranya maju.

Sementara itu, di Indonesia, pemerintah bersama rakyat belum mampu mengelola perbedaan dengan baik, sehingga seringkali perbedaan tersebut memicu benih-benih perpecahan.Menurutnya, jika saja seluruh rakyat bersama pemerintah mampu mengelola perbedaan dengan baik, maka benih-benih perpecahan tidak akan tumbuh subur di negeri ini, bahkan yang terjadi Indonesia dipastikan menjadi salah satu negara maju.

\section{b. Budaya Politik Identitas di}

\section{Kecamatan Ketungau Hilir}

Tidak diketahui pasti kapan sebenarnya muncul budaya politik identitas di wilayah Kecamatan Ketungau Hilir. Namun, walaupun demikian politik identitas tersebut saat ini sudah menunjukkan peningkatan yang cukup significan.Ini dikarenakan pandangan masyarakat terhadap politik jauh lebih baik dari sebelumnya. Disamping itu, kemunculan politik identitas juga disebabkan masuknya para pendatang dari luar wilayah, bahkan luar pulau. Keadaan tersebut secara tidak langsung memberikan corak tersendiri dalam wajah perpolitikan di tingkat ranting.

Keberagaman suku dan subsuku warga yang mendiami wilayah Kecamatan Ketungau hilir berimbas pada beragamnya persepsi terhadap politik identitas yang ada.Keberagaman persepsi itu selanjutnya membentuk opini publik. Masyarakat secara perlahan mengiring diri mereka pada keterkotakan berdasarkan kesamaan suku dan agama.

Perlahan, namun pasti keterkotakan tersebut semakin melebar hingga dewasa ini. Adanya keterkotakan itu seakan jadi jurang pemisah dan menyebabkan timbulnya jargon dukungan terhadap kandidat berdasarkan latar belakang suku dan agama. Budaya politik demikian ternyata akhir-akhir ini semakin ramai diperbincangkan sampai pada kalangan masyarakat bawah. Dukungan tersebut, bukan tanpa alasan. Melainkan masyarakat banyak bercermin pada fakta secara lokal di tingkat kabupaten kota, provinsi bahkan pusat.

Responden berinisial M, seorang guru PKn di SMP 7 berpendapat bahwa menguatnya budaya politik identitas dewasa ini merupakan reaksi 
masyarakat terhadap kandidat berdasarkan pada latar belakang agama dan suku. Mayoritas mereka akan memberikan dukungannya melihat latar belakang kandidat bersangkutan. Menurutnya, dukungan tersebut disisi lain merupakan sesuatu yang bersifat wajar, sebab salah satu kedekatan manusia secara psikologis di bangun berdasarkan kesamaan ikatan suku dan agama.

Di lain pihak, apabila dukungan tersebut dilakukan melalui cara yang kurang bijak, pada akhirnya dapat berakibat fatal dan merugikan banyak pihak. Inilah yang bisa menjadi sumber permasalahan besar karena dapat memicu konflik vertikal maupun horizontal.

$$
\text { Selanjutnya, responden }
$$

berinisial Y, guru PKn SMP 3 berpendapat bahwa politik identitas di wilayah Kecamatan Ketungau Hilir sebenarnya sudah lama terbentuk, hanya saja sebagian warga baru menyadari beberapa waktu terakhir ini. Kita menyadari betul bahwa politik identitas tersebut sangat penting. Namun, walaupun demikian tidak diperbolehkan secara terang-terangan mengungkapkannya di depan publik, sebab setiap suku dan agama mempunyai kedudukan sama untuk menjadi pemimpin pada saat ini dan masa mendatang.

Fakta ini terlihat jelas dalam siklus kepemimpinan bidang eksekutif di Kabupaten Sintang beberapa dekade terakhir, dimana kandidat yang terpilih secara bergantian berdasarkan agama dan suku berbeda. Namun, yang sering menjadi permasalahan adalah ketika masyarakat memberikan dukungan saat kampanye sering keluar jalur sehingga setiap waktu dapat memantik api perpecahan.

\section{c. Perkembangan Politik Identitas di Kecamatan Ketungau Hilir}

Waktu terus berputar bersamaan dengan perubahan zaman. Peristiwa yang telah terjadi pada masa lalu hendaknya mampu dijadikan sebagai pelajaran berharga guna membangun negeri ini menjadi lebih baik. Tidak ada perjalanan sebuah bangsa yang mulus. Kemajuan yang didambakan dengan sendirinya meminta pengorbanan besar dari seluruh rakyat. Jika rakyat bisa bersatu melaksanakan visi dan misi sama, niscaya negara mengalami kemajuan.

Peristiwa sejarah masa lampau terlalu pahit untuk dikenang. Namun, sampai kapan kita harus berlarut dalam 
kondisi demikian? Haruskah kita pasrah tanpa melakukan trobosan? Pada tahun 1928, para pemuda dari berbagai latar belakang daerah, agama dan suku bersatu membentuk perkumpulan dan menghasilkan ikrar Sumpah Pemuda yang cukup menggetarkan jiwa para penjajah. Kondisi bangsa yang terjajah menimbulkan perasaan senasib untuk bersama-sama berjuang melepaskan diri dari penindasan. Rakyat berjuang dengan caranya sendiri maupun berkelompok guna mencapai tujuan yang sama, yakni kemerdekaan. Perjuangan yang cukup panjang, pada akhirnya membuahkan hasil, berupa kado kemerdekaan, pada 17 Agustus 1945.

Setelah memasuki alam kemerdekaan, awalnya berjalan dalam damai dan aman. Namun, seiring bertambahnya usia kemerdekaan serta bergantinya generasi, perbedaan pandangan dalam membangun bangsa mulai muncul.Disadari atau tidak, perbedaan pandangan tersebut sebenarnya merupakan ancaman terhadap keutuhan NKRI. Sebab, masing-masing suku dan agama ingin mendominasi atau dengan kata lain ingin menjadi yang terdepan. Untuk mencapai visi terdepan, seringkali melakukan perbuatan kurang terpuji dengan menyudutkan pihak lain yang berada di luar kelompoknya.

Ketika Indonesia berada di zaman Orde Baru, perbedaan tersebut berusaha di redam pemerintah dengan harapan membendung benih perpcehan. Namun, apabila kita telaah lebih dalam sebenarnya kala itu secara tidak langsung bangsa Indonesia di kuasai oleh kelompok mayoritas. Ini dapat dibuktikan setelah pemilu, kelompok minoritas kebanyakan tidak mampu menembus benteng yang telah dibangun sangat kuat. Alhasil, mereka tetap saja kembali meniti jalan semula, yakni sebagai rakyat biasa.

Setelah Orde Baru berganti dengan Reformasi, berbagai etnis berlomba-lomba menunjukkan taringnya, ibarat harimau bangun dari tidur panjang. Untuk itu, setiap pemilu, mereka selalu berusaha memperjuangkan wakilnya berdasarkan kesamaan suku dan agama guna menduduki jabatan eksekutif dan legeslatif. Perjuangan tersebut mempunyai alasan "lebih enak berurusan dengan wakil kita yang mempunyai kesamaan suku dan agama”. 
Responden berinisial S, guru PKn SMP 1 berpendapat bahwa kemunculan politik identitas khususnya di wilayah Kecamatan Ketungau Hilir pada dasarnya tidak terlepas dari suhu politik di tanah air yang lebih banyak memperhitungkan dari segi suku dan agama itu sendiri. Peristiwa demikian sudah bersifat nasional. Artinya, bukan hanya berlaku di Kalimantan Barat dan Kecamatan Ketungau Hilir. Menurutnya, sebenarnya di wilayah kita ini, kemunculan politik identitas belakangan, jika dibandingkan dengan daerah lain.

Penduduk asli khususnya, terlalu lama terlena dengan eporia politik di negeri ini. Dukungan terhadap kandidat berdasarkan agama dan suku, baru mulai terjadi di atas tahun 2000-an silam, yakni pada pemilu 2004. Kesadaran tersebut terutama dikarenakan tingkat pendidikan masyarakat yang semakin baik.

Disamping itu, mereka kebanyakan belajar dari pengalaman masa lalu serta seturut Undang-Undang yang mengatakan bahwa setiap orang berhak memilih dan dipilih menjadi pemimpin. Berangkat dari adanya payung hukum tersebut, maka warga, terutama penduduk asli mulai berani memberikan dukungan terhadap kandidat dengan kesamaan latar belakang suku dan agama.

Responden lain berinisial $\mathrm{M}$, guru PKn SMP 2 mengatakan bahwa perkembangan politik identitas khususnya di wilayah Kecamatan Ketungau Hilir baru-baru ini mulai menunjukkan peningkatan yang cukup significan. Hal tersebut terbukti dari jumlah kandidat yang mencalonkan diri, baik sebagai legeslatif maupun eksekutif. Antusias warga memberikan dukungan juga meningkat tajam. Namun, besarnya dukungan yang diberikan masyarakat berdasarkan agama dan suku, tidak berlangsung lama. Dengan kata lain, dukungan tersebut perlahan mulai bergeser.

Ini dikarenakan faktor kekecewaan sebagian besar masyarakat sebab, kandidat yang mereka dukung dinilai tidak mampu memperjuangkan kepentingan masyarakat secara umum. Peristiwa tersebut, menurut " $M$ " terjadi pada pemilihan Bupati Sintang 2016 yang lalu. Waktu itu, kandidat yang mencalonkan diri ada tiga orang. Dua diantaranya berasal dari penduduk dan suku asli Sintang. Setelah pemilihan berakhir, ternyata yang keluar sebagai pemenang adalah kandidat yang tidak 
berasal dari dan bukan penduduk Kabupaten Sintang asli.

Sebagian besar masyarakat berpendapat bahwa "Kami telah berusaha memberikan dukungan kepada kandidat berdasarkan kesamaan suku dan agama, namun kenyataan yang diterima masih jauh dari harapan". Untuk itu, kami memberikan dukungan pada kandidat lain yang tidak mempunyai kesamaan suku dan agama, siapa tahu dia mampu memperjuangkan kepentingan kami sebagai masyarakat bawah.

\section{Hasil}

\section{a. Politik Identitas di Kecamatan Ketungau Hilir}

Hasil penelitian yang telah dilakukan, ditemukan bahwa guru PKn berpandangan politik identitas pada dasarnya sangat diperlukan. Ini dimaksudkan untuk menunjukkan jati diri sebagai anak bangsa. Mereka beranggapan, tanpa politik identitas, orang akan kehilangan prosesinya sebagai masyarakat. Politik semacam ini di era sekarang justru harus diperkuat, namun bukan berarti berlebihan (cauvinisme). Jika sudah berlebihan, berarti mulai mengarah pada sentimen kesukuan maupun keagamaan yang pada akhirnya dapat memecah belah persatuan dan kesatuan bangsa.

Tidak ada satu pun manusia yang bisa terlepas dari politik identitas. Sebab, politik identitas tersebut sebagai pertanda darimana individu berasal. Hendaknya generasi muda jangan sampai menghilangkan atau justru malu mengaku bahwa dirinya berasal dari etnis dan suku tertentu. Hal seperti ini tidak berlebihan, malahan sangat diperlukan.

Justru kedekatan manusia secara emosional bisa terbangun melalui keluarga, kawan akrab, kesamaan hoby, satu ruangan tempat kerja, teman sejawat, kesamaan suku maupun agama. Yang menjadi sumber masalah, ketika politik identitas kurang menghargai perbedaan ataupun keberagaman.

Awalnya, politik identitas di Kecamatan Ketungau Hilir tidak terlalu menonjol. Ini dikarenakan masyarakat setempat masih ikut arus dari pusat (secara nasional). Seiring berjalannya waktu, dan mulai terbukanya kran perpolitikkan di tanah air, kesadaran masyarakat pun muncul. Akhirnya, pada pemilu 2004, politik identitas mulai terasa sampai pada kalangan akar rumput (kelas bawah). Dukungan masyarakat mulai mengalir terhadap 
kandidat yang mempunyai kesamaan suku dan agama dengan mereka.

Kejadian ini, sebenarnya bermula secara nasional, dimana masyarakat sering menyaksikan di berbagai media bahwa hanya etnis tertentu saja yang cenderung menguasai. Oleh karena itu, masyarakat di pedalaman kemudian mulai menyatukan persepsi guna memberikan dukungan terhadap kandidat dengan latar belakang serupa dengan mereka. Maksud dari dukungan tersebut, antara lain: (1) supaya masyarakat mempunyai jalur khusus terhadap pengambilan kebijakan; (2) adanya jalur khusus tersebut, sekiranya dapat memberikan efek langsung terhadap pembangunan di daerah pedalaman.

Fakta di atas didasari semakin meningkatnya pendidikan masyarakat dan juga kesadaran politik yang semakin baik. Disamping itu, masyarakat setempat sebagai penduduk asli mulai menyadari bahwa penduduk pendatang memberikan dukungan mereka terhadap kandidat yang juga punya kesamaan suku maupun agama. Dengan demikian, sejak pemilu 2004 sampai 2019, mayoritas masyarakat mendukung kandidat yang mempunyai kesamaan dengan mereka. Namun, walaupun demikian, ada yang unik, yakni pada pemilukada Bupati Kabupaten Sintang 2016 yang lalu.

Pada saat pemilukada tersebut, dua kandidat berasal dari penduduk asli di Sintang. Sementara itu, satu kandidat bukan penduduk asli. Yang berhasil keluar sebagai pemenang adalah kandidat yang statusnya bukan asli penduduk Kabupaten Sintang. Setelah dilakukan kajian, ternyata masyarakat banyak kecewa dengan kandidat yang mempunyai kesamaan suku dan agama dengan mereka. Sehingga mereka banyak yang memberikan dukungannya pada kandidat lain, dengan harapan kandidat tersebut mampu membangun lebih baik dari sebelumnya.

\section{Simpulan}

Semua warga negara yang telah berumur 17 tahun dan atau telah menikah mempunyai hak untuk memilih dan di pilih. Ini sesuai dengan isi Undang-Undang Nomor 7 Tahun 2017 pasal 1 ayat (34) "Pemilih adalah warga Negara Republik Indonesia yang telah genap berumur 17 (tujuh belas) tahun atau lebih, sudah kawain atau sudah pernah menikah". Dalam memilih dan memberikan dukungan, setiap orang tidak bisa diinterpensi dari pihak 
lain, sebab dukungan tersebut

dalam bidang legeslatif maupun berdasarkan hati nurani masing-masing eksekutif.

individu.

Apabila dalam perjalanannya, ada oknum yang dengan sengaja mengarahkan masyarakat untuk mendukung kandidat tertentu, maka hal tersebut merupakan bentuk pelanggaran yang mestinya harus di tindak tegas oleh pihak berwajib. Jika terus dibiarkan, akan berdampak terhadap maraknya politik uang (money politich). Sementara, politik uang merupakan bentuk politik yang kurang sehat dalam penegakkan demokrasi.

Secara umum, menguatnya politik identitas di wilayah Kecamatan Ketungau Hilir mulai muncul pada pemilu 2004. Ini dikarenakan terbukanya kran perpolitikkan di tanah air, tingkat kesadaran masyarakat dalam berpolitik sudah jauh lebih baik, tingkat pendidikan masyarakat semakin meningkat, dan juga belajar dari pengalaman bahwa dekade sebelum tahun 2000, perpolitikan tingkat lokal dan nasional di kuasai oleh kelompok tertentu saja. Sementara kelompok lain seakan "dikekang" supaya tidak berkembang atau dengan kata lain, supaya mereka tidak muncul sebagai pemimpin di tingkat lokal dan nasional

\section{Daftar Pustaka}

Aman. 2007. Metodologi Penelitian Kualitatif. Makalah Disampaikan dalam Diklat Penulisan Skripsi Mahasiswa Pendidikan Sosiologi yang Diselenggarakan Oleh HIMA Pendidikan Sejaran FISE UNY. Tidak diterbitkan.

Bogdan dan Biklen. 1992. Qualitative Research for Educations. Jakarta: PT. Dunia Pustaka.

Muhadjir, Noeng. 1996. Metodologi Penelitian Kualitatif. Yogyakarta: Rake Sarasin.

Nasution, S. 2003. Metode Penelitian Naturalistik Kualitatif. Bandung: Tarsito.

Nawawi, Hadari. 2007. Metode Penelitian Sosial. Yogyakarta: Gadjah Mada University Press.

Rahmat, P.S. 2009. Penelitian Kualitatif. Jurnal Equilibrium Edisi Januari-Juni. Vol. 5. No. 9.

Sugiyono. 2011. Metode Penelitian Pendidikan, Pendekatan Kuantitatif, Kualitatif \& $R \& D$. Bandung: PT. Alfabeta.

Syaodih, Nana Sukmadinata. 2010. Metode Penelitian Pendidikan. Bandung: PT. Remaja Rosdakarya. 
Susila, Indrawati. 2015. Pendekatan Kualitatif untuk Riset Pemasaran dan Pengukuran Kinerja Bisnis. Jurnal Manajemen dan Bisnis (Benefit) Edisi Juni. Vol. 19. No. 1 .
Undang-Undang No. 7/ 2017.Pemilu. Online.

Undang-Undang No. 39/1999. Hak Azasi Manusia. Onlin

Undang-Undang No. 7/ 2017.Pemilu. Onl 